\title{
Race, Citizenship and Social Order in William Shakespeare's Othello
}

\author{
Mustapha Bala Ruma \\ Department of English, Faculty of Arts and Social Sciences, University of Malaya, Kuala Lumpur, 50603, Malaysia \\ E-mail: mbrumah@yahoo.com
}

Received: 19-10-2013

Accepted: 28-11-2013

Published: 01-03-2014

doi:10.7575/aiac.ijalel.v.3n.2p.34

URL: http://dx.doi.org/10.7575/aiac.ijalel.v.3n.2p.34

\begin{abstract}
This paper examines the issue of race in Shakespeare's Othello. It attempts to show that race is a very important issue raised by Shakespeare in the play in his eagerness to highlight the racial problems confronting Europe in the seventeenth century. In this play he attempts to expose the racial prejudice that exists in the Venetian society in particular and Europe in general. He also attempts to subvert the European feelings of racial superiority against the blacks in particular and people of other races in general. He sets out to do this by making a black man (Othello) marry a white woman (Desdemona) of an aristocratic extraction against the will and wish of her father. This inter-racial marriage may not in reality be possible in the seventeenth century, but all the same Shakespeare contrived it to be so, possibly as a way of foregrounding future change in European attitudes toward other races. The paper also looks at how individual citizens of a city-state like Venice can constitute themselves as threats to its social well being, by allowing their personal interests to override the national ethos. In this regard the activities of Othello, Iago and Roderigo are examined.
\end{abstract}

Keywords: citizenship, race, racism, revolt, social order

\section{Introduction.}

To say that race is a visible presence in Othello is an understatement. The play as a whole revolves around, among other things, race, love, jealousy, revenge, and destruction. The issue of Race however is its power house. Othello wears race like a badge, and flaunts it to audience and readers alike like a medal. This is probably because of the fact that the play is about Othello the Moor and he is black - or so we are made to believe .Keeping the controversy surrounding his hue and color at bay, one thing that is incontrovertible is that Othello is a non-European person. That makes him to be the 'Other'; an outsider in Europe and that makes race an important issue in the play. As a matter of fact Othello's blackness is the primary signifier of his otherness in this foreign city-state. Yet, the fact that the problem of race is so obvious in the play poses the danger of ignoring it, of taking it to be an over worn theme.

Admittedly, there are tons and tons of critical works written about race, racism, racial stereotype, and the like on the play. However, as Michael Nell (1998) argues "To talk about race in Othello is to fall into anachronism: yet not to talk about it is to ignore something fundamental about the play that has rightly come to be identified as a foundational text in the emergence of modern European consciousness--" (361).Even so, it is noteworthy, that Shakespeare was not the first European dramatist to use a black Moor as a protagonist in his plays. That credit goes to Thomas Peely who in his 1588 play The Battle of Alcazar introduces his black moor character Muly Mohamet. According to Ruth Cowhig (1985) "He [Mohamet] is portrayed as cruel and treacherous, and his evil is directly associated with his blackness..." (2).

The impact of The Battle of Alcazar on the imagination and passion of its Renaissance audience was tremendous. It probably sets the standards for judging black characters in subsequent plays, especially in England. These standards are often constructed based on the European racial stereotyping that found justification in science and Christian theology. For instance, Kenneth Parker (1985) has aptly demonstrated in his essay that European writers like Leo Henkin have used race as a means of classifying human beings, "with Europeans at the top of the evolutionary tree, and with primitive peoples as representing earlier stages of European development..." (193).Based on the literature available at the time on Darwin's evolution, there is no doubt that the Negros belongs to the "primitive peoples" suggested by Henkin. Europeans also find the rationalization of racism in Christian theology. In this respect they locate it in the biblical story of Ham the accursed son of Noah, whom they consider to be the "father" of all colored people. And as noted by Kok Su Mei (2006:34) even the devil is always depicted in "black garb" by the Europeans in order to accentuate this racial stereotype. At this juncture, it is important to note that Othello was not the only play in which Shakespeare uses a black character. He also employs black characters in plays such as Titus Andronicus (1590) whose black character Aaron is portrayed as wicked and malevolent. In this play the color of Aaron is not left in doubt either. He is variously described as 'raven-colored,'a black-devil ', and 'a coal-black Moor'. Aaron in this play is obviously portrayed in a more sinister way than Othello. There are also black characters in Anthony and Cleopatra as well as The Tempest. 
As mentioned earlier, race is central to understanding the tragedy of Othello. The play itself is built around it from the beginning to the end. For example, in the opening scene of the play, the duo of Iago and Roderigo use the trajectory of race to further their agenda. They use it firstly to arouse Brabantio to anger (and possibly to action) and secondly to malign the character and personality of Othello as a means of undermining him in the future. In this regard the villain Iago urges the pliant Roderigo to, "Call up her father/ Rouse him, make after him, poison his delight/proclaim him in the streets, incense her kinsmen" [1.1.67-69].And when finally he chances upon Brabantio, Iago continues his campaign of incitement in an obscene language:

Your heart is burst; you have lost half your soul,

Even now, now, very now, an old black ram

Is tupping your white ewe! Arise, arise

Awake the snorting citizens with the bell

Or else the devil will make a grandsire of you,

Arise I say! [1.1.85-90].

Roderigo also helps in this racial diatribe by calling Othello variously as 'the thick lips', 'lascivious Moor', and a 'wheeling stranger'. In their use of language, especially in reflecting their hostility to Othello, they both use foul and racist language. Their diction and imagery clearly demonstrate their racial prejudice against Othello. They are not only angry with him for marrying Desdemona (a white woman), but are also horrified with the marriage because he is a Moor. Hence their agenda is build around a resolve to wreck this marriage no matter what it takes. But since they know that they can neither attack the honor nor cast doubt in the valor of Othello, the only weapon they have left is to employ racial sentiments against him. In this respect they try to enlist the support of Brabantio who though liberal with Othello at first, now has an axe to grind with him .In an attempt to do this they employ racist and obscene language as shown above. In this regard I quite agree with Martin Okin(1987) who suggests that "the language of these men [Iago and Rodrigo] ignites a similar tendency lurking within ...Brabantio" (168).Thus, even the liberal attitude he exhibited towards Othello at their meetings before now is shown to be deeply superficial in this episode.

Having succeeded in arousing him to anger, Brabantio too uses racist language to attack the relationship between Othello and his daughter. He therefore sees the action of Othello as a threat to the Venetian social order, and if it were to be sanctioned by the senate, then, "Bond-Slaves and pagans shall our statesmen be" (1.2.99). Despite the fact that Brabantio is fully aware that Othello is neither a slave nor a pagan, he all the same projects both onto the general, referring also to the "sooty bosom/of such a thing as thou" (1.2.99)(169).Brabantio also consider the union between Desdemona and Othello as a "treason of the blood!" He sees in it the corruption and violation of a white woman by a black man. In this he reechoes the same sentiments with Iago who earlier in the play foresees the product of such union in racial terms. He pompously tells Brabantio that if the marriage is allowed to survive, flower, and bear fruits, he [Brabantio] will have "nephews" that "neigh to you" and "Coursers for cousins and jennets for germans!" $[1.1$ 109112].Thus in spite of his initial generosity to Othello, Brabantio nonetheless quickly lapses into racism after Othello elopes with Desdemona. In this regard he is not better than either Iago or Roderigo; the three are racial bigots that hate Othello though for different reasons. For instance, Iago hates him because he bypasses him and selects Cassio as his lieutenant; he also suspects him of cuckolding his wife Emilia:

Iago: I hate the Moor

And it is thought abroad that 'twixt my sheets

He's done my office. I know not if't be true,

But I for mere suspicion in that kind

Will do as if for surety. (1.3.385-390).

Roderigo on the other hand hates Othello because of his realization that in spite of his color and race, Desdemona prefers Othello over him. Brabantio also hates him in equal measure because at first he suspects him of bewitching Desdemona, and when this turns out to be untrue, he hates him for instigating a revolt in his house hold. In fact, Desdemona's revolt makes him to lament that, "I had rather to adopt a child than get it" (1.3.193). He also cautions parents, especially fathers to be wary of their daughters by saying, "-Fathers, from hence trust not your daughters' / minds/By what you see them act" (1.1 168-170).

By marrying Desdemona, Othello incurs the wrath of Brabantio, Iago, and Roderigo. And if it were not for the war imminent between Venice and the Turks at this particular moment, it is doubtful whether the senate of Venice will bless the marriage. However, this is only a speculation, because as demonstrated in the play with the exception of these three, all the other people that have something to do with the matter are sympathetic to Othello. Yet, there is still the danger that Othello is not a fully integrated person in the Venetian society. In spite of his service to the state, his gallantry in the battle field, and his conversion to the state religion [Christianity/Catholicism] of Venice, he still remains "the Moor"inMoor" in the eyes of many Venetians. To this majority, he is still an outsider and a stranger-something to be used as a means to an end[fighting their wars].Significantly, Othello on his part too, seems to be deluded by his popularity among the Venetian aristocrats. He mistakenly believes that because he is their army commander, he is one of them. His whole conduct, including his marriage to Desdemona hinges on this belief. In this regard, it is worth noting that Othello in his euphoria and over confidence of his achievements in the military services he renders to the state, 
erroneously believes that he is fully integrated into the Venetian society. Hence his over confidence makes him not to realize that his position in the Venetian society is nothing more than that of a mercenary, a soldier to be hired in fighting the society's foreign wars. As John Wain (1971/1982) rightly points out in his book Othello, in spite of their open nature and acceptance of Othello as their army commander, the Venetians still have their reservations about him. Consequently "the Venetian aristocrats will certainly not admit him [Othello] to their inmost society, and they certainly do not want their daughters to marry Moors" (14).And as noted by Nabil Matar and Rudolph Stoeckel (2005:235) in Othello Shakespeare has made it evidently clear that Othello "... is in the Christian polis but not part of it." Analogically speaking, Othello is in the "polis" physically but is excluded from it socially.

From Wain's, Matar and Stoeckel's submissions above, it could be deduced that despite his military rank and position, Othello is still seen as an outsider and most certainly an inferior to the aristocratic senators like Brabantio. The Venetian society tolerated him only because of his military prowess. In this regard, the relationship between Othello and the city of Venice is parasitic rather than symbiotic in nature. In this respect, the Venetian society is the parasite, whereas Othello the soldier is the victim/host. As Camille Well Slights (1997) points out his "sense of personal and social identity [in the Venetian society] is based on individual achievement and merit. He owes his position in Venetian society to personal ability and the chances of war" (379). There is no doubt that in the world of the text, Othello has gallantly and dutifully demonstrated his unreserved love for his adopted city-state by staking his life in its defense. These efforts however, are not enough to guarantee him full citizenship of this Mediterranean city-state because of his color.

\section{Venetian Citizenship in the $17^{\text {th }}$ Century.}

During the $17^{\text {th }}$ century Venice was a Republican city-state that was governed by a group of men honorably referred to as 'the Senators'. These men of wealth, prestige, and power formed the council that decides on matters of importance in the Venetian society. Membership of this committee was constituted from the nobility/aristocracy which was the highest echelon of the Venetian society. It is worth noting that during this period the Venetian society was organized on a tripartite structure consisting of the nobility or patrciate at the top, followed by the class of cittadini originari or Venetian citizens by birth(the elite class) and lastly the general public outside the aforementioned two groups referred to as the popolani. Unlike the two first groups, this group consists of both native and foreign residents. Politically, there was a marked social division between these groups in terms of functions and responsibilities. For instance, while the patrciate were entrusted with decision making in all matters of importance to the state, the cittadini originari were expected to participate in the Venetian bureaucracy. The popolani on the other hand were not assigned any special role, hence they constitute a large and willing labor force to be used by the state whenever the need arises. It is interesting to note that members of this last group mostly consists of migrant Muslims, Jews, and other people from adjacent citystates such as Florence and Cyprus. It is equally important to note that people from this group can experience social mobility from the popolani to full-pledged citizens only by religious conversion to Catholicism. As noted by Natalie Rothman (2006:57), "Conversion in early modern Venice operated as a mechanism for the transformation of Muslims and Jews...into properly-constructed Catholic subjects, capable of filling normative kinship and institutional roles in Venetian society." The importance of converting "heathen" Muslims and Jews to Catholicism in Venice can be seen in the eagerness with which both the government and the wealthy citizens of Venice support the Pia Casa dei Catacumeni (Holy House of the Catechumens). ${ }^{1}$ Conversion therefore served as an incentive for Muslims, Jews, and others to become fully integrated citizens of Venice. In spite of this dangling opportunity however many residents might have chosen to remain foreigners living in Venice without the full privileges of Venetian citizenship. In this group you will find professional soldiers who are ready to sell their expertise to the city-state whenever the need arises. It is perhaps instructive to note that as a Republican city-state that prides itself on independence and freedom, Venice does not have a professional standing army. Instead it depends mostly on the services of mercenaries in defending itself against external enemies. That clearly explains how Othello, Cassio, and Iago find themselves in the Venetian militia that is sent to fight the Turks in Cyprus. As a matter of principle the Venetian city-state in the $17^{\text {th }}$ century was historically morbid of a professional standing army. They are afraid that an army that is purely made of Venetian citizens could one day be a threat to the security of Venice. In this regard, Mark Matheson (1995) has aptly noted that Venice in the $17^{\text {th }}$ century promulgated a law that "no Venetian citizen could have more than twenty-five men in his command (124)." It was probably this Venetian policy to checkmate and prevent any "conquering Ceaser" (Matheson 124) from turning against the republican state that opened the way for men like Othello to assume a prominent role as a mercenary in the Venetian militia.

\section{The Triple-assault on Venetian Social Order in Othello.}

Many scholars have described Venice in the seventeenth century as an open, mercantile and republican city-state. It was also portrayed as a liberal society that welcomed strangers with open arms so long they have something to contribute to its growth and security. For example, Camille Wells describes Venice as "an ideal [place] in which civic virtue produces a powerful, free society that in turn protects and nurtures the honor and freedom of its members" (380).William Wordsworth on his part aptly described Venice as "the eldest Child of Liberty..." (cited in Honigmann 1997: 8).It was also "the pleasure capital of Europe" (Honigmann 9). During the Renaissance period Venice is also famous for its power to acknowledge people based on their "individual merit" (Wells 380). Their English neighbors according to Daniel J Vitkus (1997) views Venice as "a sphere of tolerance and rationality located between the twin tyrannies of papal superstition on one hand and Islamic "paganism" on the other" (163). This morbid fear of Islamic expansionism into the heart of Europe towards the end of the seventeenth century had no doubt helped in inspiring 
playwrights like Shakespeare to produce plays that depict the turban wearing Turk as an enemy to be tamed and if possible converted to Christianity.

Similarly, writing about the importance of Venice in the seventeenth century, Helen Gardner (1982) in her essay "The Noble Moor" argues that Venice "is a cosmopolitan society in which there are two kinds of bonds between its members, the bond of economic interest and the bond of personal friendship, which may coincide, run parallel with each other or conflict..."(214). There is no doubt that it is the cosmopolitanism of Venice that allows it to welcome strangers like Othello in its midst. It is noteworthy that in the world of the text it is not only Othello the Moor that is a stranger in the Venetian society; there are other characters that are not natives of Venice. For instance, Andrew Hadfield (2005) points out that both "Iago and Roderigo are Spanish names" (5), which also makes them to be strangers and outsiders like Othello, though their foreignness is clearly disguised because they are whites.

From the tapestry of the play, it could be deduced that Othello, Iago, and Roderigo are a mortal threat to the social well being of the Venetian society. For example, Othello is welcome with open arms, but only as a mercenary. In part it is his foreignness that alienates him from Brabantio.ItBrabantio. It therefore becomes an embarrassment to Brabantio that Othello should have the audacity to propose marriage to Desdemona - a white Venetian daughter of an aristocrat. By so doing he has overstepped the bounds of decency, and is therefore a threat to the Venetian society. The paradox is very glaring - an army officer that is employed to protect the integrity of the society from any external threat has turned out to be a threat to that very society. By failing to respect the implicit color line drawn by the Venetian society, Othello is posing a serious danger to the social coexistence of that society. When viewed against the fear of racial miscegenation widely spread in the Venetian society at that time, his marriage to Desdemona is clearly a transgression. At the end of the play the grief Othello induces to Brabantio makes him [Brabantio] to die prematurely .He also murders the very woman he defies many odds to marry and then in a desperate move to save his name takes his own life.

There is no doubt that Iago the villain is also a threat to the social order of the Venetian society. As a matter of fact, Iago poses the most threatening danger to the existence of the Venetian society. Like Othello he too is a soldier employed to keep the sanctity of the state, but he ends up turning against the same society with vengeance. There is little to doubt also that Iago is estranged from the Venetian society. He is angry with it for appointing Othello as his commander-in-chief. He also becomes doubly estranged when the same Othello bypasses him and appoints Cassio as his second- in- command. Having considers himself injured by both Othello and the Venetian society, he vows to take revenge against both. In pursuing this agenda, he attacks Othello directly by instigating him to murder Desdemona. Similarly, he also attacks the Venetian society indirectly by breeding discontent within its army and also by causing the death of other innocent citizens. Equally important in this regard are his attempts to persuade Roderigo to pursue Desdemona in spite of the fact that she is married to Othello. Iago also poisons the mind of Othello against his lieutenant Cassio thereby creating a rift between them. This could lead to a breakdown of discipline in the Venetian army, thereby jeopardizing its security through mutiny. It is noteworthy that in the play mutiny did take place though on a limited scale. This could be seen where both Cassio and Roderigo at the prompting of Iago fight and stab each other. It also extends to the murder of Desdemona by Othello and his own eventual self annihilation. From all these it could be seen that Iago from the beginning of the play to its end, is nothing but a nuisance that constitute a grave threat to the Venetian social order. It is similarly important to note that Iago does all these satanic activities in order to satisfy his personal and selfish agenda.

In an almost similar fashion Roderigo is also a threat to the social well being of the Venetian society. He allows himself to be willfully manipulated by Iago when he urges him to follow Desdemona to Cyprus:

Iago: Put money in thy purse, follow thou

The wars defeat thy favor with an usurped beard;

I say, put money in thy purse. It cannot be that

Desdemona should long continue her love to the

Moor - put money in neither thy purse — nor he his to her. [1.3. 340-44]

It is with exhortations like this that Iago leads Roderigo by the nose to his ruination. In pursuing Desdemona in spite of her marriage to Othello, Roderigo constitutes himself into an obstacle to the Venetian idea of civility. His role at the beginning of the play in arousing Brabantio to anger against Othello is to say the least odious. Equally his brawl with Cassio in Cyprus at the instigation of Iago portrays him as an irresponsible young man without proper social upbringing. His gullibility is also a threat to his society. As a matter of fact, by conniving with Iago to wreck the marriage of Desdemona and Othello, Roderigo definitely threatens the moral and social fabric of the Venetian society.

\section{Conclusion}

From the discussion so far it could be seen that race is a fundamental issue in the seventeenth century Venice of Shakespeare's Othello. The whole atmosphere of the play is permeated with its effects. It is the fulcrum around which the plot of the play revolves. Perhaps, what makes it central is the deep awareness of all the dramatis personae to the color of Othello the Moor. In the world of the play, there is no gainsaying that the race of Othello is highly publicized and emphasized. His name resonates with his color from the mouth of both his friends and foes. To his friends and admirers like the Duke, Desdemona, and Cassio; he is "Othello the Moor"; whereas to his enemies like Iago, Brabantio, and Roderigo, he is "an old black ram", "a Barbary horse", and "a lascivious Moor!" In this play ordinary human 
failings that spring from Othello are interpreted as a product of his race and color. The combination of these things make race to be an important issue in the play.

Similarly, it could also be seen that the behavior and actions of Othello, Iago, and Roderigo when studied against the demands of social civility and stability of Venice are disastrous. As a matter of fact, each of these three persons' behavior constitutes a serious threat to the moral, social and economic well being of the Venetian society - the very society that gives them a space to earn a living and express their individualism.

\section{References}

Cowhig. R.(1985). "Blacks in English Renaissance drama and the role of Shakespeare's Othello." In Dabydeen, D.(Ed.). The Black Presence in English Literature. Manchester: University Press.

Gardner, H. (1971)1982. “The Noble Moor.” In Wain, J. Ed. Othello. London: Macmillan Press Ltd.

Hadfield, A. (2005). "Shakespeare and Renaissance Europe." In Hadfield, A. and Hammond, P. Eds. Shakespeare and Renaissance Europe. London: Thomas Learning. Honigmann, E.A.J. (ed).(1997). Othello. 3rd edition. London: The Arden Shakespeare.

Matar, N. and Stoeckel, R. (2005). "Europe's Mediterranean Frontier: The Moor." In Hadfield, A. and Hammond, P. Eds. Shakespeare and Renaissance Europe. London : Thomas Learning.

Matheson, M. (1995). "Venetian Culture and the Politics of Othello." Shakespeare Survey: An Annual Survey of Shakespeare Studies and Production. Vol. 48, 123-133.

Nell, M. (1998). "Mulattos" "Blacks" and "Indian Moors": Othello and Early modern Constructions of Human Difference." Shakespeare Quarterly. 49 (4) Winter, 361-374<http://www.jstor.org/stable/2902233.

Okin, M. (1987). "Othello and the plain face of Racism." Shakespeare Quarterly. 38(2) Summer, 166-188 $<$ http://www.jstor.org/stable/2870559.

Parker, K.(1985). “The revelation of Caliban: ‘the black presence' in the classroom.” In Dabydeen, D. (1985). Ed. The black presence in English literature. Manchester: UP. Rothman, N. E. (June 2006). "Becoming Venetian: Conversion and Transformation in the Seventeenth Century Mediterranean." Mediterranean Historical Review, 21(1), 39-75, Routledge, Taylor \& Francis Group. <http://www.enotes.com/topics/othello/critical essay/venetian-culture-and-politicsothello. Retrieved: October 16, 2013.

Slights, C. W. (1997). "Slaves and Subjects in Othello." Shakespeare Quarterly.48(4) Winter, 377-390. $<$ http://www.jstor.org/stable/2871250. Retrieved October 10, 2011.

Su Mei, Kok.(2006). "Racial Stereotyping in The Merchant of Venice." In Yeow Agnes et al (eds). Critical Voices from Malaysia: Perspectives on English Literature. Kuala Lumpur: University of Malaya Press.(pp31-48)

Vitkus, D. J. (1997). "Turning Turk in Othello: The Conversion and Damnation of the Moor." Shakespeare Quarterly.48(2)Summer,145-176. <http://www.jstor.org/stable/2871278. Retrieved October 10, 2011.

Wain, J. (1971/1982). Othello. London: Macmillan Press Ltd.

\section{Note:}

1. The Pia Casa dei Catacumeni is the Catholic Church's institution in $16^{\text {th }}$ and $17^{\text {th }}$ century Venice that oversee and manage Jewish and Muslim converts. It is responsible for their baptism as well as their insertion into the social fabric of Venetian society through apprenticeship, marriage, and employment opportunities. For more on this see E.N. Rothman, "Becoming Venetian: Conversion and Transformation in the Seventeenth century Mediterranean." Mediterranean Historical Review, Vol. 21, No 1, June 2006. 